REVIEW

\title{
Thorium minerals in Sri Lanka, history of radioactivity and thorium as a future energy source: a compendium to commemorate the International Year of Chemistry 2011
}

\author{
K. Tennakone* \\ Nanotechnology Laboratory, Department of Electronics, Faculty of Applied Sciences, The Wayamba University of Sri Lanka, Kuliyapitiya.
}

Submitted: 22 March 2011 ; Accepted: 29 April 2011

\begin{abstract}
The discovery of radioactivity more than a century ago and vigorous research on the subject thereafter has transformed the world scientifically and technologically through a deeper understanding of the nature of matter. Two stalwarts among the illustrious pioneers in this field were Lord Ernest Rutherford and Madame Marie Curie. Both were physicists by training and both won the Nobel Prize for Chemistry. While Rutherford's work was more inclined towards physics, enabling elucidation of the structure and mechanics of the atom, Curie's discoveries instantly catalyzed a revolution in chemistry. The year 2011, designated as the International Year of Chemistry, celebrates the centennial anniversary of award of the Chemistry Nobel Prize to Marie Curie.
\end{abstract}

When Marie Curie separated radium from pitchblende, the curious researchers and amateurs started turning stones around looking for pitchblende and other radioactive minerals. In this endeavour, a British planter in Sri Lanka (then Ceylon) collected heavy rock samples, similar in appearance to pitchblende, and dispatched them to two eminent researchers pursuing studies on radioactivity in Britain. Analysis by chemists in Britain and subsequent prospecting by the then Ceylon Geological Survey enabled identification of thorium oxide thorium and silicate minerals, thorianite and thorite, containing a very high percentage of thorium. A number of major discoveries in radioactivity by outstanding pioneers in this field have been conducted using Ceylon thorianite and thorite. Most reputed physics and chemistry journals in the first three decades of the twentieth century carry articles on these discoveries making conspicuous references to Ceylon thorium minerals. The International Year of Chemistry is an appropriate moment to review the history of radioactivity in relation to thorium minerals of Sri Lanka. Coincidently, Sri Lanka and several other countries are currently focussing much attention on the use of thorium as a safe, environmentally benign and lasting source of energy. This work examines discoveries in radioactivity made by pioneers of this field, using Ceylon thorium minerals, giving historical anecdotes on use of Sri Lankan minerals in understanding fundamental properties of matter. The important aspects of uranium-thorium mineral chemistry, formation of radioactive mineral sand placer deposits and generation of thorium based nuclear energy are also discussed, because of current relevance of these topics to Sri Lanka.

Keywords: History of radioactivity, monazite, radioactive placers, thorianite, thorite, thorium energy.

\section{INTRODUCTION}

Thorium is a naturally occurring radioactive element nearly four times more abundant than uranium. Unlike uranium, thorium in the earth exists in the form of one single isotope ${ }_{90} \mathrm{Th}^{232}$ with a half-life of 14 billion years, compared to 4.5 billion for ${ }_{92} \mathrm{U}^{238}$. Half-lives of all other isotopes of thorium are much shorter than the age of the earth, accounting for their absence in the terrestrial environment. Cosmically, thorium and uranium synthesis had taken place in supernovae explosions (Arnett, 1996) with similar production cross-sections; the longer half-life of the former is the intrinsic cause of its higher abundance. These two elements are positioned in the actinide series of the periodic table on either side of protactinium, and similarities and differences in their chemistry accounts for the mode of distribution of the two elements in the earth's crust (Titaeva, 2000; Hazen, et al., 2004). During evolution of the earth from protoplanetary to fluidic and until early stages of magmatic differentiation, uranium and thorium have gone through similar chemical pathways. As thorium and uranium species do not form solutions with abundant silicates in the magma (Titaeva, 2000; Hazen et al., 2004), when the magma cooled, the two elements precipitated as oxides and silicates or formed adducts with phosphatic mineral phases. An 
initial cause in mineralogical evolution, differentiating thorium from uranium seems to be metamictization (Hazen et al., 2004). Metamictization or damage to the crystal lattice of a radioactive mineral due to alphaemission is more pronounced in uranium rich phases than in thorium rich phases, because of the faster decay rate of uranium. Accumulation of lead and helium gas during radioactive decay also enhances degradation of uranium rich minerals promoting separation of thorium and uranium. The next step in the evolutionary process of rocks, influencing deviation in geochemistry of uranium away from thorium appears to be condensation of water on cooling of the earth (i.e. Hazen et al., 2004). Higher solubility of uranium species compared to thorium equivalents causes preferential leaching of uranium from composite minerals, enriching thorium and depositing uranium in sedimentary rocks. Again as photosynthetic organisms evolved and proliferated, the oxygenic conditions seem to have created distinctively different geochemical influences on thorium and uranium (Titaeva, 2000). Thorium is stable only in the oxidation state +4 , whereas in uranium the oxidation states $+6,+5$ and +3 remain stable in addition to +4 species. As higher oxidation states of uranium are more soluble in water, the mobility of uranium has been further enhanced after evolution of the oxygen atmosphere. A self-sustaining nuclear chain reaction had taken place on the earth 2 billion years ago, in the vicinity of a present day uranium mine in Oklo, Gabon, continuing for five hundred years (Cowan, 1976). For a chain reaction to occur with water as a moderator, uranium in the ore needs to be enriched well above $0.7 \%$ of $U^{235}$ (the average $U^{235}$ content of present day uranium ores) in order to achieve criticality (Cowan,1976). As the oxygen atmosphere began to evolve around 2 billion years ago, it appears that oxygen dissolved water percolating through rocks has been the cause of uranium enrichment of the Gabon ore. A consequence of the above important distinctions between chemistry of thorium and uranium is that in general, the former is found in association with minerals derived from igneous rocks, whereas the latter occurs in igneous as well as sedimentary rocks. At the same time, similarity of the crystal chemistry of thorium and uranium is evident from the fact that thorium minerals also contain some uranium and vice versa.

Mineralogists have identified and elucidated the crystal structure of more than one hundred thorium containing minerals (Nininger, 1954). Sri Lanka is richly endowed with thorium minerals including ones with the highest recorded weight percentage of thorium. The well documented examples being thorianite (Coomaraswamy, 1904 a ; Dunstan, 1904; Ramsay, 1904; Dunstan, \& Blake, 1905; Dunstan, \& Jones, 1906;
Crooks, 1908), uranothorianite (Dunstan,1904), thorite (Crooks, 1908), ekanite (i.e. Anderson et al, 1961), zirkelite (Crooks,1908), baddeleyite (Fletcher,1893), samaraskite, (Kulp \& Volchok, 1952), fergusonite (Crooks, 1908), monazite (Dunstan, 1905) and thorium pyochlore (Crooks, 1908). Of the above, thorianite and thorite discovered by Ananda K. Coomaraswamy (Coomaraswamy, 1903) and W.D. Holland in 1903-1904 are intimately connected with the history of radioactivity. The pioneers in the study of radioactivity who won the Nobel Prizes for their work ; Lord Rutherford, Madame Curie, Frederick Soddy, Sir William Ramsay, Francis W. Aston, Otto Hahn, Theodore William Richards and many other prominent persons in the history of radioactivity have worked with Ceylon thorianite and thorite. In their work, Ceylon thorium minerals have been used in elucidation of radioactive decay law, understanding elemental transformation in radioactivity and the concept of isotopes, radio active series, discovery of new radioactive isotopes, determination of the age of the earth and as a terrestrial source of helium. The issues of reputed scientific journals of the first few decades of the 20th century, carry articles with conspicuous references to Ceylon thorianite and thorite.

\section{Sri Lankan minerals in the hands of foreign investigators and discovery of thorianite}

In early days, the interest of Sri Lankans in minerals was mainly in the context of gem mining and processing of iron ore. Prospecting, mining and processing of gem minerals and lapidary has been a matured industry in Sri Lanka for more than two thousand years. Unusual materials of high specific gravity and hardness, though not of gem quality, had also received the attention of miners. When a basket of gem gravel is vigorously swirled, centrifugation settles the heaviest components first. Folklore in gem mining areas of Sri Lanka refers to pebbles so heavy that even a palmful cannot be readily lifted. Probably these stones were either thorianite or thorite; most gems and other minerals associated with gem gravel have densities well below that of thorium rich crystals.

Occasionally minerals from Sri Lankan gem pits have gone to persons with inquiring minds in far away lands. The Italian philosopher Pliny (24 AD) observed pyroelectricity in tourmaline of different colours, matching precisely with those found in Sri Lanka (Bostock \& Riley, 1898). As Pliny also had acquaintance with traders coming from Sri Lanka, it is very likely that tourmaline referred to by Pliny originated in Sri Lanka. In 1717, French chemist and physician Louis Lemery demonstrated pyroelectricity to the French Academy using a tourmaline sample, said to have been 
collected from a river bed in Ceylon (Kunz, 1915). During the demonstration, he said that this 'Cingalese Stone' acts quite differently from a magnet, because it attracts and then repels the same object. Following the work of Lemery, the German physicist Theodor Aepinus demonstrated that when a stone of tourmaline from Ceylon was heated, positive and negative charges develop at the ends of the crystal- phenomenon of pyroelectricity (Kunz, 1915). According to another historical record a mineral called "Turmale", which attracts objects when heated, has been imported to Holland from Ceylon in 1704 believing it has magical powers (Lang, 2005). Even earlier than Pliny, the Greek philosopher Theophrastus of Eresos (371-87 BC), a pupil of Plato and the successor to Aristotle at the prestigious Lyceum in Athens had observed pyroelectricity in a crystal supposed to be tourmaline (Lang, 2005). Greeks were lavishly fond of gems; perhaps merchants traveling via the silk route carried tourmaline from Sri Lanka to Greece.

A further example of experimentation with a Sri Lankan mineral leading to an important finding has been the discovery of zirconium (Emsley, 2001) by the German chemist Martin Heinrich Klaproth in 1789, from a gem stone referred to as 'Jargon of Ceylon'. In the post-medieval times, zircon from Ceylon was sold in Europe as Jargon or Zargun. The involvement of Persian traders in this business is evident, as Zargun in Persian means 'gold like'. The new element found in Zargun from Ceylon was named zirconium by Klaproth (Emsley, 2001). It is interesting to note that zirconium is the only chemical element first discovered using a material that had originated in Sri Lankan soil.

The first man to indulge in an extensive scientific study of geology and minerals of Ceylon is the renowned physician and chemist Dr John Davy, the brother of the famous chemist Sir Humphery Davy, posted to Ceylon Medical Services by the British Government in 1821. John Davy identified and recorded the location of occurrence and chemical composition of a large number of minerals and measured specific gravities (Davy, 1821). Sir James Emerson Tennent, the Colonial Secretary of Ceylon from 1845-1850, further expounded the work of Dr John Davy, possibly to consider economic exploitation of Ceylon minerals (Tennent, 1860). Until 1903 there was no proper Geological Survey Unit in Sri Lanka and matters related to mineralogy was looked after by the Ceylon Survey Department. In 1903 Ceylon Mineralogical Survey was established under the directorship of Ananda Coomaraswamy, previously serving as the Mineralogical Surveyor of the Ceylon Survey Department (Sorkhabi, 2008). Ananda Coomaraswamy invigorated mineralogical studies in the country, making many original contributions, most notable being the discovery of a new mineral in collaboration with the amateur mineralogist W.D Holland in 1903-1904 (Dunstan \& Blake, 1905). Analysis conducted at the Imperial Institute in London showed that this mineral is constituted of almost pure thorium dioxide (Dunstan \& Blake 1905) and the new mineral was named thorianite.

\section{Discoveries in radioactivity and Ceylon thorium minerals}

Radioactivity was a serendipitous discovery by Henri Becquerel (Becquerel, 1903) in 1896, inspired by a suggestion of the French mathematician and physicist Henri Poincare (Genet,1995), that there might be a relationship between the $\mathrm{x}$-rays discovered by Roentgen in the previous year and the familiar optical florescence, and it is worthwhile to investigate whether fluorescent materials emit radiation similar to $\mathrm{x}$-rays. Becquerel undertook this study using uranium salts known to acquire brief phosphorescence upon exposure to light. He exposed uranium salts to sunlight and tested for invisible rays using a covered photographic plate. On a day when the Paris skies were fully cloudy, unable to do the experiment, he wrapped up the uranium salts and photographic films together and put them in a drawer. When the sky became clear after few days, Becquerel decided to resume the experiment, but nevertheless developed the film and observed that it has been exposed. Being curious about Becquerel's finding, Marie Sklodowska Curie, then a student reading for a doctoral degree in physics at Sorbonne, began to work on Becquerel phenomenon, named 'radioactivity' later by her and found that not only uranium but thorium salts also emit this radiation; however compounds of no other element possessed this property. When Marie Curie completed the doctoral dissertation in 1898, the radioactivity of potassium $\mathrm{K}^{40}$ was not known [discovered by Sir J.J. Thompson in 1905 (Thompson, 1905)]. Curie emphasized that the degree of radioactivity depends only on the amount of uranium or thorium present and not on other chemical attributes of their compounds and therefore an atomic property of the element itself - one of the most far reaching inferences that paved the way for elucidation of the chemical structure of matter. Marie Curie also found that the parent uranium ore pitchblende is more radioactive than pure uranium. Suspecting the cause to be a presence of other radioactive substances in pitchblende, Curie pursued painstaking experimentation, and discovered the elements polonium and radium 1898 (Curie, 1911). In 1903, Marie Curie and her husband Pierre Curie shared the 1903 Nobel Prize in Physics with Henri Becquerel for their contributions towards understanding the nature of radiation discovered by Becquerel. Marie 
Curie was hononred with a Nobel Prize for Chemistry in 1911 for her contributions to chemistry in discovering new elements polonium and radium. The year 2011 is celebrated as the International Year of Chemistry to coincide with the $100^{\text {th }}$ anniversary of the award of Nobel Prize to Marie Curie. Findings of Becquerel and Marie Curie aroused much excitement among physicists and chemists in Europe, rushing to gain more understanding of the nature of radioactivity and also to search for other radioactive elements in minerals, found even in lands beyond their territories.

In colonial days, the men of letters among the British community in Ceylon seem to have kept abreast of the latest developments in Europe, through newspapers and magazines. Some of them living in remote areas of the country as tea planters were even publishing correspondence in the journal Nature. According to Ananda Coomaraswamy, the occurrence of heavy mineral resembling pitchblende in an area close to Balangoda was brought to his notice by a tea planter named Holland, living in Dikmukalana, Sabragaumuwa District. $\mathrm{Mr}$ Holland who collaborated with Ananda Coomaraswamy in thorianite prospecting was not only a mineral enthusiast but also business minded. Mr Holland living in his tea estate at Dikmukalana inquisitively explored mineralogy in the neighbourhood for curiosity as well as for profit (Dunstan \& Blake, 1905). Around 1902 he had collected some heavy black gravels from a nearby gemming area, and suspecting the material to be pitchblende, he sold it to the famous English chemist Sir William Ramsay who received the shipment in February1903 (Ramsay, 1904). Sir Ramsay was working on radioactivity and isolation of inert gases at the University College, Gower Street, London. Previously in 1895 he had identified helium in the radioactive mineral cleveite and was keenly interested in looking for entrapped gases in other radioactive minerals. Ananda Coomaraswamy had examined samples from Mr. Holland more carefully and found the same mineral in a vein of pegmatite in Gampola. Samples collected by Ananda Coomaraswamy and Holland were sent to Prof. W. Dunstan at the Imperial Institute in London for analysis. Prof. Dunstan identified the material as a new mineral constituted largely of thorium dioxide and named it thorianite (Dunstan \& Blake, 1905). The work was published in Nature on $31^{\text {st }}$ March 1904 under the title "The Occurrence of Thorium in Ceylon" (Dunstan, 1904). Being aware of the Dunstan's submission, Sir Ramsay hurriedly published his results in the same journal on $7^{\text {th }}$ April 1904 under the title "New Mineral from Ceylon (Ramsay, 1904), where he acknowledges purchase of 5 cwt. of the mineral from Mr. Holland and says that he is awaiting further supplies of the mineral from the same source in Ceylon. Ramsay detected helium in this new thorium mineral confirming his earlier observation of helium in cleveite. Sir Ramsay earned the Nobel Prize for Chemistry in 1904 for his discoveries of inert gases.

To meet the request for thorianite by Sir Ramsay and other researchers in the United Kingdom, Mr. Holland had made much effort to collect larger quantities of this mineral. Having to face difficulties of buying "nampu" (gem gravel) from miners, he obtained a prospector's license and examined many gem bearing areas in the Sabaragamuwa District and succeeded in finding a good source of thorianite in the bed of the Kuda Pandioya near Kudurugala in Bambarabotuwa (Dunstan \& Blake, 1905). Around 1905-1910, Ceylon thorianite fetched a high price in London because of its demand for radioactivity research and as a new source of thorium for manufacture of gas mantels. The demand for thorianite in Britian prompted the Colonial Office in Ceylon to issue a notice in 1904, informing intending prospectors that the Government for three years would undertake to levy no royalty on this mineral, except in case of extraction from crown lands, where permission to wash will be by agreement on liberal terms (Great Britain Board of Trade, 1906). Presumably, on basis of this notice of the Government of Ceylon, amateur prospectors had continued collection of thorianite from streams and river beds of Ratnapura, Himiduma and Galle (readily identifiable as heavy black cubic crystallites) until 1940s. Clearly, there must have been authorized or unauthorized dealers importing the material. According to folklore, after Hiroshima, Nagasaki incidents, the general public was somewhat alarmed to hear that thorianite has some connection to the atom bomb.

Two other pioneers in the study of radioactivity who got involved in experimentation with Ceylon thorianite while working with Sir Ramsay are Otto Hahn and Fredrick Soddy. Otto Hahn's career in radiochemistry and nuclear physics, finally leading to the discovery of nuclear fission and the honour of a Nobel Prize, began with Ceylon thorium minerals. Otto Hahn after completing a doctoral degree in chemistry from a German university went to London in 1903 to work with Sir William Ramsay. The task assigned to Otto Hahn by Ramsay was separation of radium from residues of Ceylon minerals. Radium was discovered earlier in pitchblende by Madame Curie, and Ramsay suspected that radium is also there in Ceylon thorianite (Hoffmann, 1993). Otto Hahn successfully extracted radium from the residues of Ceylon minerals and found that, after removal of radium, the residue continued to be radioactive. After further investigations, Otto Hahn was able to prove that an intensely radioactive substance "a new element" chemically indistinguishable from thorium 
exists in the residue and named it radiothorium (Hahn, 1905). On $8^{\text {th }}$ March 1905, the London newspaper Daily Telegraph reported Otto Hahn's finding as discovery of a new radioactive element extracted from a mineral in Ceylon named thorianite. From University College London, Otto Hahn moved to Montreal to work with Rutherford and continued to work on radiothorium using Ceylon minerals. Subsequently radiothorium was shown to be an isotope of thorium with mass number 228 .

The other person who came to work with Sir William Ramsay in 1903 and gained worldwide fame was Fredrick Soddy (Soddy, 1922). He worked with Ramsay for one year and got acquainted with Ceylon thorianite and throrite while working there, before moving to University of Glasgow. He confirmed inseparability of thorium and radiothorium observed by Otto Hahn and showed that thorium and several other radioactive elements exist in different forms with differing half-lives but identical chemical properties (Soddy,1904; Soddy,1919; Badash,1979). He succeeded in establishing a chain of radioactive transformations in thorium and uranium and firmly established the concept of "isotope" (Soddy, 1904; Soddy, 1919; Soddy, 1922). In his Nobel lecture Soddy acknowledged the use of Ceylon thorite, making the statement "In my own work, 30 kilograms of Ceylon thorite containing 55\% thorium, $1 \%$ uranium and $0.4 \%$ lead was hand-sorted and from 20 kilograms of selected pieces, 80 grams of metallic lead were separated" (Soddy, 1922).

Around 1903-1904, Sir Ramsay had been so curious of Ceylon thorianite, that almost everybody who came to work in his laboratory during this time worked on Ceylon thorianite. When the Japanese chemist Masataka Ogawa visited his laboratory in 1904, Ramsay asked him to work on Ceylon thorianite, saying that there are two new unidentified elements in this mineral (Yoshihara, 2008). With a limited supply of thorianite, Ogawa carried out extensive chemical separations and spectroscopic measurements and came to the conclusion that a new element exists in Ceylon thorianite, but he did not succeed in ascertaining the atomic weight (Ogawa, 1909). Ogawa returned to Japan carrying the samples of Ceylon thorianite with Ramsay's permission, continued analysis in his laboratory and concluded that what he found is the element of atomic number 43, fitting the vacant place in the periodic table referred to as the position of eka-manganese and named the new element nipponium in 1909 (Ogawa, 1909). Later on, it became clear that the element of atomic number 43, now known to be technetium is not found in the earth's crust and the element Ogawa detected in thorianite in 1909 has been rhenium, related to manganese in its chemical properties
(Yoshihara, 2008). This was after the discovery of rhenium by Walter Noddack and Otto Berg in 1925 and nipponium was deleted from the periodic table.

\section{Ceylon thorium minerals and atomic weight of lead}

A puzzling issue that cropped up during studies on radioactive transformations was that the element lead in different radioactive mineral samples gave different atomic weights and also not the same as lead from nonradioactive sources (Kauffman, 1982). Many workers have used thorite and thorianite samples from Ceylon to elucidate this problem (Soddy \& Hyman, 1914; Richards, 1914; Soddy, 1915; Soddy, 1917). In 1917 Fredrick Soddy reported that the atomic weight of lead in Ceylon thorite is 207.74, whereas that in ordinary lead is 207.20 (Soddy, 1917). Notable is the work of the American Chemist Theodore William Richards who accurately measured the atomic weight of lead in Ceylon thorianite and pitchblende (Richards, 1914) and arrived at similar conclusions. Finally the problem was understood as a consequence of the existence of many stable isotopes of lead. Mass spectroscopy carried out by Francis Aston enabled accurate estimation of the mass number of lead isotopes. Now it is known that lead exists as four stable isotopes $\mathrm{Pb}^{204}, \mathrm{~Pb}^{206}, \mathrm{~Pb}^{207}$ and $\mathrm{Pb}^{208}$; of these $\mathrm{Pb}^{204}$ is cosmogenic (synthesized in supernovae) while the others are radiogenic being the end products of the decay of uranium, thorium and actinium.

\section{Thorium emanations}

Another problem that originated from the study of radioactivity where Ceylon thorianite played an important role has been the understanding of the nature of some mysterious substances, which in the early days of radioactivity was referred to as radioactive emanations. In 1899 Rutherford found that the radioactivity of thorium oxide, as ascertained by the discharge of an electrometer varied in a peculiar way, different from uranium compounds. In contrast to uranium, thorium activity was found to enhance if the thorium sample is housed in a compartment with the electrometer, suggesting that the emanation resembled a gas (Rutherford, 1906; Thomas, 2008). Otto Hahn, working with Ramsay in 1905, found that air bubbled through a solution of Ceylon thorianite in nitric acid acquires radioactivity, supporting the gas hypothesis of the emanation (Hahn, 1905; Hahn, 1907; Hoffmann, 1993). Furthermore, Otto Hahn noticed that after bubbling air, emanation depletes out, but regenerates in the solution after some time, conclusively proving that the emanation is a gaseous decay product of thorium. Now it is known that the thorium emanation or Thoron is the isotope $\mathrm{Rn}^{96}{ }_{220}$ of radon with a half-life $55.6 \mathrm{~s}$. 


\section{Helium in Ceylon thorianite}

Thorianite and the other radioactive minerals from Sri Lanka have been a good source of helium for many experiments. Sir Ramsay determined the density of helium at atmospheric pressure using helium extracted from Ceylon thorianite by reacting it with acids (Ramsay \& Soody, 1903). He also attempted to liquefy helium obtained by the same method but did not succeed, because of the difficulty of reaching low temperatures. The key person versed in liquefaction of gases at the time was Sir James Dewar at the Royal Institution, London (Dewar, 1927). Dewar, not well disposed towards Ramsay and possibly having no access to sufficient quantity of Ceylon thorianite, attempted to collect helium from a spring in Bath, South-West England. At the same time (1905), S. Olszewski, another authority on liquefaction of gases in Poland, received Ceylon thorianite from Ramsay (Delft van, 2008). However, Olszewski's cooling system could not go below $9{ }^{\circ} \mathrm{K}$, indicating the necessity of improving the refrigeration technique to liquefy helium. Dewar's archrival in cryogenic techniques Kamerlingh Onnes in Holland possessed good facilities for reaching very low temperatures, but was also short of helium gas. Finally Onnes managed to get monazite from North Carolina through his brother who was a diplomat, extracted helium and successfully liquefied it in 1908. It is interesting to note that James Dewar was so ingenious and found a way to test the liquefiability of helium using very little thorianite. He constructed a Crookes radiometer with a small side tube containing charcoal, inserted a grain of Ceylon thorianite and sealed it after evacuation (Delft van, 2008). The radiometer did not respond to thermal radiation as there was no gas inside. When the thorianite grain inside the radiometer bulb was heated for a while, the minute amount of helium released turned the radiometer vanes. Even if the tube containing charcoal was cooled to liquid hydrogen temperature (lowest temperature attainable at that time), the radiometer continued to turn. However, the situation would have been different if the radiometer was filled with any other gas at very low pressure. If not for Onnes's precedence, given sufficient time Dewar would have found a way to cool charcoal to lower temperatures and measure the liquefaction temperature of helium using very little helium. It appears that Dewar had got the sample of thorianite to do this experiment from Sir Willaim Crookes himself, the inventor of the radiometer. Crookes, a close associate of Dewar, has also obtained thorianite and other minerals (thorium containing fergusonite and zirkelite) from Ceylon in 1904 (Levy, 1915).

After discovery of helium in cleveite, Ramsay and several other chemists in Europe had examined minerals collected from many parts of the world including yattotantalite and baddeleyite from Rakwana in Ceylon (Levy, 1915). These are radioactive minerals containing small quantities of thorium and uranium. Much effort diverted towards search for helium in minerals was not entirely to pursue studies in radioactivity. A nonflammable gas less dense than air was considered as a boon for safe transoceanic transport and warfare using airships. Some prematurely jumped to the conclusion that Ceylon thorianite could provide enough helium, before realizing the prohibitive cost and unavailability of sufficient quantities of this material. Finding a nonflammable gas to fill airships became a matter of urgency when British admiralty fired incendiary bullets towards a German Zeppelin in 1917 and found that the airship did not catch fire, although bullets pierced it (Stuart, 1929). At this time, Ceylon monazite containing a very high percentage of thorium became very important as monazite is far more abundant than thorianite (Science Service, 1930). However, economic unfeasibility of extracting helium from monazite to fill airships was again realized. Extraction of helium from radioactive minerals for commercial purposes was abandoned after the finding of helium in natural gas. Helium generated in subterranean radioactive rocks accumulates into natural gas enriching it up to $2-3 \%$.

\section{Ceylon thorianite and determination of the age of the earth}

Ceylon thorianite has played a key role in estimation of the age of the earth, when the idea of radiometric dating was first proposed by Ernst Rutherford in 1905. As his pet subject in radioactivity has always been alpha decay, Rutherford argued as follows. When mineral containing uranium undergoes alpha decay, neutralized alpha particles get trapped in the mineral as helium. The amount of helium generated can be related to the age of the mineral, provided the half-life of uranium is known. At the time, Rutherford made this statement, Ceylon thorianite was the best material to do this experiment with as is evident from the statement made by Rutherford in his talk titled "Some cosmical aspects of radioactivity" presented at the Astronomical Society of Canada in 1907 (Rutherford, 1930), where he states, "I have here some crystals of a new mineral thorianite, found few years ago in Ceylon, which contains about 12 per cent uranium and 70 per cent thorium. This mineral on heating evolves remarkably large quantity of helium - more than $10 \mathrm{cc}$ per $g$ of the mineral. Now it is almost certain that helium stored in this mineral has been produced by breaking up of the radium contained in since formation of the mineral. Assuming the rate of production of helium by radium already mentioned, it can be calculated with confidence 
that age of the mineral thorianite is at least 500 million years. When the constants involved in this calculation are accurately determined, I feel great confidence that this method will prove utmost value in determining with accuracy the age of radioactive minerals and indirectly the geologic strata in which they are found". Today, to a person who is familiar with the modern theory of radioactive transformations, the technical flaws in Rutherford's brilliant originality is obvious. Nevertheless, it was the beginning of radiometric age determination, which has superseded other techniques of age estimation.

Subsequently, many workers followed Rutherfords idea more rigorously as findings of other investigations in radioactivity became available. Robert John Strutt, Lord Rayleigh's son, pursued Rutherford's idea in 1907 and estimated the age of sample of thorianite from Galle, Ceylon as 280 million years (Boltwood ,1907; Strutt, 1909; Dalrymple, 1992). Another sample of thorianite from the Sabaragumuwa District had given a somewhat smaller value, as the helium content was lower (Nier, 1939). Values of this order for the age of the earth made biologists unhappy, being too low to account for the evolutionary process and information gained from the study of fossils. One of the problems with the helium method of age determination is loss of helium from the mineral. A more reliable method, also suggested by Rutherford, was to determine the amount of lead, the end product of the radioactive decay series. Bertram Boltwood in Yale, who had worked with Rutherford, accurately determined lead content of a large number of radioactive minerals and calculated the corresponding ages. According to Boltwood's analysis, the oldest rock, one of 2200 million years, happened to be a sample of thorianite from Galle (Boltwood, 1907). Arthur Holmes who had worked with Robert John Strutt at the Imperial College, London, continued the work on determination of lead in minerals to estimate the age of earth and reported 1600 million years for a sample of thorite from Ceylon (Holmes, 1927). The above age estimations of Boltwood and Holmes were not very accurate as details of the radioactive decay chains of thorium and uranium remained largely unknown at that time. Subsequently, there were many refinements on the basis of further understanding of radioactive decay of uranium and thorium. Holmes in 1927 estimated the age of Ceylon thorianite as 585 million years (Holmes, 1927). The work of Holmes gave much credibility to radioactive dating of rocks. In 1939, A.O. Nier (Nier, 1939) analysed the isotopic constitution of lead in Ceylon thorianite and deduced 531,461,485 million years as ages corresponding to $\mathrm{Pb}^{206} / \mathrm{U}^{238}, \mathrm{~Pb}^{208}$ / $\mathrm{Th}^{232}$ and $\mathrm{Pb}^{207} / \mathrm{Pb}^{206}$ ratios.
Ekanite : a new gem quality radioactive mineral discovered by a Customs Officer in Sri Lanka

A thorium containing highly radioactive gem quality rare mineral first discovered in Sri Lanka, which deserves special reference is ekanite (Anderson et al., 1962). This mineral is named after Mr F.L.D. Ekanayake, a Customs Officer in Colombo who was also a gemologist with an inquiring mind. In $1953 \mathrm{Mr}$ Ekanayake came across some cut green stones in the hands of a gem dealer in Colombo, suspected to be an imitation of polished glass (De Silva, 2008). However, Mr Ekanayake guessed that these stones could be a new variety of gems, purchased the stones from the dealer and gave it to his friend Mr R.K. Mitchell, well known for spectroscopic examination of gems (Anderson, 1974). Although Mitchell's impression was also that the material is glass, he passed the sample to B.W. Anderson at the Department of Mineralogy, British Museum of Natural History, London, for examination. Anderson had received the sample from Mitchell with a letter from Ekanayake, where he stated that "I am sure this is a new mineral". Preliminary analysis conducted by Anderson revealed presence of calcium, silica and traces of lead in the sample, again pointing to the conclusion that the material is indeed glass and passed the sample to Dr D.K. Hill, a well known glass technologist at the Department of Glass Technology, University of Sheffield for his opinion. At first, Hill had confirmed the glass hypothesis based on amorphous like characteristics seen in the Debye-Scherrer x-ray spectrum (Anderson, 1974). Subsequently, Hill found that the sample contained 27\% thorium oxide and Anderson came to the conclusion that the stone is a metamict mineral - a crystal where lattice structure is destroyed almost completely due to internal alpha irradiation from thorium. Anderson also found that the material reverts to crystallinity on sintering, enabling elucidation of the crystal structure. After nearly ten years, the results of analysis were published in Nature, naming the new mineral "Ekanite". The empirical formula of ekanite is $(\mathrm{CaFePb})_{2}$ (ThU) $\mathrm{Si}_{8} \mathrm{O}_{20}$ (Gubelin, 1962). The green colour originates from iron in the ferrous state and the uranal ion induces florescence when shined with ultraviolet light.

\section{Mille Ellen Gleditsch's experiments with Ceylon thorianite}

Any discussion on the history of radioactivity is incomplete without a reference to Mille Ellen Gleditsch. She was Madame Curie's assistant involved in industrial production of radium who subsequently undertook many studies in radioactivity (Lykknes et al., 2004). Gleditsch was the first woman to hold a Chair of Chemistry 
in Norway and considered as a pioneer in the field of radiochemistry. During 1913-1914 she worked at Yale with Bertram Boltwood on determination of the age of radioactive minerals including Ceylon thorianite. Gleditsch was a careful experimentalist; she measured the ratio of radium to uranium in a number of radioactive minerals and found that the ratio is significantly higher in Ceylon thorianite (Gleditcsch, 1908).

The radioactive series leading to production of radium was unknown at the time and Gleditsch's thorianite anomaly became a puzzle as well as a clue to gain further insight into decay modes of uranium. Boltwood showed that a higher radium/uranium ratio in thorianite is a consequence of the existence of an intermediate decay product of uranium, which was named ionium. Although ionium was not a new element as postulated by Boltwood, it resolved the puzzle. Ionium was later identified as $\mathrm{Th}^{230}$ and subsequent work of Soddy enabled complete elucidation of the $\mathrm{U}^{238}$ decay chain. Apart from her contributions to radiochemistry, she deserves to be honoured in the International Year of Chemistry as a proponent of encouraging women to take up science (Lykknes, 2004) - an aspiration of the International Year of Chemistry. On two occasions, Gleditsch had been denied academic positions on grounds of gender. Subsequently, because of this experience, Gleditsch promoted women to science.

\section{Radioactivity in zircon}

Pure zircon (zirconium silicate, $\mathrm{ZrSiO}_{4}$ ) is not radioactive as its constituent elements are not radioactive elements. However, natural zircons including some gem quality stones are radioactive, because of the presence of thorium and uranium by isomorphous substitution for zirconium in the zircon lattice. Substituted thorium or uranium remain permanently fixed and are extremely difficult to remove. For this reason, the regulations for hazardous materials in some countries classify zircon as radioactive. For thousands of years Ceylon zircon has attracted attention as a precious stone and more recently as a prototype material for many scientific investigations, notably study of metamictization and age determination of rocks (Gotteried, 1953; Gotteried et al., 1956; Davis \& Krough, 2003).

When thorium or uranium atoms in the zircon lattice disintegrate, emitting energetic alpha particles, recoil effect or momentum transfer to the lattice disrupt the lattice locally (Murakami et al., 1991). Further, the elastic collisions of alpha particle their, on path through the lattice, create atomic displacements. Millions of years of internal radiation resulting from the presence of a few thousand ppm of thorium and/or uranium causes macroscopic changes in zircon crystal, ultimately converting the material to amorphous or glass like structure. In this metamictization process zircon crystal expands, decreasing the density and the refractive index (Ewing et al., 2003). Gem quality Sri Lankan zircon is the standard material used in many studies on metamictization (Ewing et al, 2003). Recently it has been found that the degree of metamictization seen in zircon from Sri Lanka is lesser than what one could expect from nearly 500 million years of alpha irradiation (Nasdala et $a l ., 2004)$. This observation is important in understanding the geological history of Sri Lanka (Nasdala et al., 2004). As metamictization tends to reverse at higher temperature, the results implicate that rocks bearing zircon was in an environment of higher temperature for a prolonged period (Nasdala et al., 2004). The reason why gem quality zircon from Sri Lanka is valued more than those from other regions seems to be related to the fact that damaging effect of metamictization is less in Sri Lankan zircon.

Zircon from Sri Lanka is also the standard material used to develop the technique of zircon based radiometric dating of rocks. When zircon crystallizes during cooling of magma, thorium and uranium of matching ionic radii and coordination readily substitute into zirconium, but lead is excluded from the lattice and associates itself with potassium of similar ionic radius. Thus lead in zircon is an exclusive product of radioactive decay of thorium and uranium. Most estimates of the age of Sri Lankan rocks determined by this method agree with the thorianite age of Holmes. Recently, zircon from Sri Lanka has also been used to test whether radiogenic lead gets leached, and the finding was that some leaching indeed occurs under hydrothermal conditions.

\section{Radioactive mineral sand in Sri Lanka}

The stretches of Sri Lankan coastline are richly endowed with monazite sand containing thorium, uranium and a number of rare earth elements (Dunstan, 1905; His Majesty's Stationery Office, 1920; Wadia \& Fernando, 1946; Wickramaratne, 1986; Wijayananda \& Nootan, 2000). Elevated background radiation level originating from concentration of these ores has also been recorded (Mahawatta, \& Hewamanna, 1991). In many locations enrichment and the quantity available is adequate for commercial mining (Dunstan, 1905; Wadia \& Fernando, 1946; Wijayananda \& Nootan, 2000 ). The current demand for monazite is mainly for extraction of rare earths. Rare earths find wide range of applications such as phosphors, electroceramics, catalysts, alloying agents and in the glass industry. Two most valuable rare earth 
elements present in monazite, neodymium and samarium are used for making permanent magnets. In the first few decades of the $20^{\text {th }}$ century demand for monazite was mainly for recovery of thorium and cerium oxides needed to manufacture gas mantles (Kremers, 1985). The best material exhibiting cando-luminescence (the process by which certain solid materials convert heat into visible light) was found to be a mixture of thorium and cerium oxides. Before wide electrification, manufacture of mantles for gas and oil lamps has been a profitable industry. When Ceylon thorianite was discovered in 1903 (Coomaraswamy, 1903; Imperial Institute, 1916 ; Pascoe, 1924; Overstreet, 1967), the British gas mantle industry was enthusiastic as it is much easier to make thorium nitrate from thorianite than from monazite (His Majesty's Stationery Office, 1920). At this time, thorium nitrate production happened to be a German monopoly based on monazite supplies from Brazil and Travancore (now Trivandrum), India (Pascoe, 1924; Abraham, 1998). However, within few years, prospecting conducted by the Ceylon Mineral Survey indicated that the projected supply of thorianite cannot meet the requirements of the gas mantle industry and emphasis shifted to monazite. In 1904, Mineralogical Survey of Ceylon reported finding of commercially viable quantities of monazite beach sand deposits in Ceylon (Dunstan, 1905; His Majesty's Stationary Office,1920). During World War I demand for gas mantles escalated and the British Government in 1918 commissioned a monazite separation plant in Beruwala equipped with an electromagnetic separator (Current Industrial News, 1917). A latent reason behind Britain's interest in processing Ceylon monazite of high thorium content could also be the 1917 Zepplein incident (Science Service, 1930), which aroused the fear that Germany already possessed technology to extract helium from radioactive minerals. The British government imposed an embargo on import of monazite from countries under its empire as a precautionary measure (Abraham, 1998). The issue of monazite once again became important towards the end of the World War I, when the allied powers realized that Germany is experimenting to develop a nuclear bomb (Abraham,1998). Otto Hahn had demonstrated the fission in both uranium and thorium; however the practicability of achieving a self-sustained chain reaction using thorium remained unsettled (Abraham,1998). Consequently, monazite resources in the world were under close scrutiny by the allied powers. It is said that the delay in Travancore joining the Indian Union was connected with its monazite resources (Guha, 2007). The high value for monazite as potential nuclear fuel in breeder reactors continued until about 1950s, when availability of substantial reserves of uranium was evident from extensive prospecting. The other reason for decline of ambitions for monazite has been the difficulty of turning thorium into weapons grade fissile material in comparison to uranium (Unak, 2000).

In the coming decades, the commercial usage of thorium would certainly escalate, when utilization of greenhouse gas emission free fuels becomes a necessity and not an option (Clery, 2005; Hargraves \& Moir, 2010). India is in the forefront of this effort; from inception the Indian nuclear programme had realized the potential of using thorium (Clery, 2005; Chalmers, 2010; Hargraves \& Moir, 2010).

Monazites bearing mineral sands are derived from weathering of continental pegmatite rocks and transport of highly stable monazite grains to alluvial basins and the ocean by running water (Kanazawa \& Kamitani, 2005). The physical mechanism of placer deposit formation leading to efficient separation of ingredients is not fully understood (Slingerland \& Smith, 1986). Minerals and sand deposited in the shallow regions of the continental shelf, where wave turbulence reaches the bottom, continuously lift up heavy sediments and transport them to the shore. Turbulence greatly helps suspension of heavy sediment in water; when the wave recedes, turbulence also decays due to frictional and viscous losses, settling more dense components first. Efficient fractionization by above mechanism of which the details remain unresolved, is a cause of the formation of placer deposits. Formation of placer deposits can be beautifully illustrated by the following observation of the author. In walking on a sandy road in Sri Lanka just after heavy rains, streaks of black deposits over sand are frequently seen. People in Sri Lanka call this graphite, without bothering to see whether the material marks paper like graphite. The author found that these deposits does not mark paper and thought it is something else, probably pieces of granite. Decades later, when the author had access to a Geiger counter, the material was found to produce counts well above the background. Clearly, these mini-placer deposits contain some monazite/thorite along with other mineral grains heavier than sand.

A closer examination of these mini-placers reveals clues to the mechanism of their formation. These deposits are more conspicuously seen in positions, where fast moving rain water digging a narrow trench spreads out at a wider opening or passes an obstacle - that is, at positions where the fluid velocity suddenly drops, ceasing turbulent agitation which keeps heavy particles in suspension. The explanation for enhancement of the deposition of heavy minerals in Sri Lankan and Indian shores during monsoon is also a result of the enhanced turbulence in the shelf during this season. A study conducted by the Radio Isotope Center, University of Colombo 
shows a clear correlation between the background radioactivity in vicinity of the shore and the wave activity (Dharmawardene et al., 1986). The Beruwala placers are concentrated in monazite, whereas those in Pulmoddai are enriched with ilmenite. A difference in the composition of primary material is most unlikely to be the cause of this difference. Presumably, this complex but spectacular separation processes is dependent on the local monsoon weather pattern, topography of the continental shelf, densities and sizes of mineral grains and other spatio-temporal factors. The studies of these effects by simulation experiments (De Costa, \& Nandadeva, 2001) and/or computational fluid mechanics would be an interesting field of research quite appropriate to Sri Lanka. Equally intriguing is the thermodynamics of placer mechanism. Placers are low entropy systems; separation of components from a randomized mixture decreases entropy, but this at the expense of energy and placer formation is a non-equilibrium process.

Monazites are phosphates of f-block elements in the periodic table. The f-block includes, lanthanides $L=$ [ $\mathrm{La}$, Ce, Pr, Nd, Pm, Sm, Eu, Gd, Tb, Dy, Ho, Er, Tm, Yb, $\mathrm{Lu}$ ] and actinides $A=[\mathrm{Ac}, \mathrm{Th}, \mathrm{Pa}, \mathrm{U}, \mathrm{Np}, \mathrm{Pu}, \mathrm{Am}$, $\mathrm{Cm}, \mathrm{Bk}, \mathrm{Cf}, \mathrm{Es}, \mathrm{Fm}, \mathrm{Md}, \mathrm{No}, \mathrm{La}]$. Monozites can be represented by a formula of the form $R_{\mathrm{x}}\left[R_{\mathrm{x}}, R_{1}, R_{2}\right.$ --- $A_{1} A_{2}$---] $\mathrm{PO}_{4}$, where $R_{\mathrm{x}}$ is most abundant rare earth , $R_{1}, R_{2}$---- are the other rare earths present, written in the order of abundance and $A_{1} A_{2}$--- are actinides. Yttrium and scandium classified as rare earths $(R)$ along with lanthanides are also present in most monazites. All the actinides are radioactive; of these $\mathrm{Th}, \mathrm{Pa}$ and $\mathrm{U}$ with sufficiently large half-lives are found in monazite minerals. Monazites contain trace quantities of short lived actinium and protactinium. The possibility of incorporating transuranium elements into a monazite type lattice has been demonstrated (Tabutea, et al., 1988). Lantanides and actinides display very similar chemical properties; one of the parameters differentiating them is the ionic radius. The trivalent ionic radii of the elements in the lanthanide and actinide series decrease with increase of the atomic number. The reason why the monazites in nature exhibits a wide range of variation in the elemental composition is not fully understood. The relative abundance of f-block elements, ionic radii and local geochemistry in the early stages of magmatic differentiation are factors influencing the composition. Again monazite is amazingly stable towards metamictization. In most thorium containing monazites $R_{x}=\mathrm{Ce}$ and $R_{1}=$ La these two elements are also the most abundant rare earths in the earth's crust. Genesis of monazites has not been fully elucidated; the insolubility of lanthanide and actinide oxides in felsic magma and their association with phosphate phases appear to be an important factor that led to crystallization of the two phosphate minerals monazite and xenotime. Generally, heavier rare earths with smaller ionic radii associate preferably with xenotime, whereas the lighter ones of larger ionic radii go into monazite(Ni et al., 1995). After primary crystallization, monazite crystals grow and changes in the geochemical environment become imprinted as different strata in the crystal. The analysis of these strata by electron microprobe for $\mathrm{Pb}, \mathrm{U}$, Th and other elements is the basis of monazite geochronology (Williams et al., 2007).

Sri Lankan monazite is relatively high in thorium content, compared to most other placer deposits of this mineral. The first chemical analysis was conducted by Prof. Dunstan at the Imperial Institute, London in 1904 using a sample from a river bed in Nirealla, Ratnapura District. Prof. Dunstan gave composition of the samples as $\mathrm{ThO}_{2} 10.75 \%, \mathrm{La}_{2} \mathrm{O}_{3} 30.06 \%, \mathrm{Ce}_{2} \mathrm{O}_{3} 26.7 \%$ and $\mathrm{P}_{2} \mathrm{O}_{5}$ 24.62\% (Dunstan, 1905; Overstreet, 1967). At that time analytical techniques lacked the resolution needed to separately identify all the rare earths. Other rare earths present had come under lanthanum and cerium. Nevertheless, this result based on wet chemistry analysis is remarkably accurate. More recent analysis of a similar inland sample of monazite from Sri Lanka has given the composition as $\mathrm{ThO}_{2} 11.6 \%, \mathrm{Ce}_{2} \mathrm{O}_{3} 28.7 \%, \mathrm{La}_{2} \mathrm{O}_{3} 21.7$ $\%, \mathrm{Nd}_{2} \mathrm{O}_{3} 6.0 \%, \mathrm{Pr}_{2} \mathrm{O}_{3} 0.9 \%, \mathrm{Sm}_{2} \mathrm{O}_{3} 0.6 \%, \mathrm{Dy}_{2} \mathrm{O}_{3}$ $0.2 \%, \mathrm{Gd}_{2} \mathrm{O}_{3} 0.1 \%, \mathrm{Ho}_{2} \mathrm{O}_{3} 0.05 \%, \mathrm{P}_{2} \mathrm{O}_{5} 27.4 \%$ (Jobbins et al., 1977).

\section{Monazite processing}

Mechanically and electro-magnetically separated monazite from placer deposits are processed by two opening routes, acid method and alkaline method (Barghusen \& Smutz, 1958; Crouse \& Brown, 1959). In the former method, the ore is digested with conc. sulfuric acid at $150-200{ }^{\circ} \mathrm{C}$ when thorium, uranium and rare earths are solubilized leaving impurities such as silica and zirconia. Various methods have been adopted for separation of components in the solubilized phase. Thorium phosphate can be precipitated by controlling the amount of acid used and dilution of the solution. However, this is inconvenient as uranium goes to the soluble phase with the rare earths. An alternative method is the precipitation of rare earths as oxalates, leaving thorium and uranium in the liquid phase. From the liquid phase, thorium and uranium can be selectively solvent extracted using amines. In the alkaline route of opening, monazite is heated with a strong solution of sodium hydroxide, when the ore breaks down into insoluble oxides of thorium, uranium and rare earths, readily separated by gravitational settling and/or filtration. Phosphate goes into solution phase and is extractable as 
trisodium phosphate. Oxide residue can be dissolved in hydrochloric or nitric acids and thorium, uranium and mixture of rare earth oxides are separated, adopting the same procedures as in the sulfuric acid process.

As sodium hydroxide can be produced in Sri Lanka using amply available salt and also because of the environmental concerns, the alkaline route appears to be the method suitable for processing monazite in Sri Lanka. The byproducts of the chlor-alkali industry, chlorine and hydrochloric acid find application in other sectors of mineral processing in the country. Chlorine can be utilized to produce titanium dioxide from ilmenite via the titanium chloride route. The waste acid in this process may be utilized to beneficiate apatite. The rare earth component from either the acid or the alkaline process is separated using ion exchange resins.

\section{Thorium as a nuclear fuel}

Human civilization will not sustain the present level of advancement unless amply abundant greenhouse gas emission free alternative energy sources are utilized. In this context, thorium seems to be the most promising alternative fuel, where the technology of power generation has been fairly well established (Unak, 2000; Clery, 2005; Chalmers, 2010; Hargraves \& Moir, 2010). The extractable energy in one kilogram of thorium equates to energy in three million kilograms of coal. Burning this amount of coal will release more than two million kilograms of carbon dioxide and significant amounts of mercury to the atmosphere. Burning coal will also generate its one tenth of weight as ash, unsuitable for disposal in populated or agricultural areas, because of the radioactivity of uranium and thorium found in concentrations exceeding that of soil. Although nuclear power generation is almost devoid of carbon emissions, conventional uranium based reactors pose many problems such as low neutron absorption cross-sections, long lived radioactive waste, proliferation of weapons grade fissile materials, high cost of chemical processing of the fuel material and the risk of Chernobyl - like accidents. Some of these intractable issues of uranium based nuclear energy technology can be satisfactorily mitigated by replacing uranium with thorium. As substantial placer deposits of monazite occur in Sri Lanka and its neighbouring countries, thorium is indisputably a good choice for future energy demands of the country.

Unlike the isotope $\mathrm{U}^{235}$ in natural uranium, thorium occurs in the earth's crust as one single isotope $\mathrm{Th}^{232}$ which is not fissile. However, neutron bombardment converts $\mathrm{Th}^{232}$ into fissile $\mathrm{U}^{233}$ via two short lived intermediates $\mathrm{Th}_{90}^{233}$ and $\mathrm{Pa}_{91}^{233}$ as follows:

$$
\begin{aligned}
& { }_{90} \mathrm{Th}^{232}+{ }_{0} \mathrm{n}^{1} \rightarrow{ }_{90} \mathrm{Th}^{233} \\
& { }_{90} \mathrm{Th}^{233} \rightarrow{ }_{91} \mathrm{~Pa}^{233}+\mathrm{e}^{-}+\underline{v}_{\mathrm{e}} \\
& { }_{91} \mathrm{~Pa}^{233} \rightarrow{ }_{92} \mathrm{U}^{233}+\mathrm{e}^{-}+\underline{v}_{\mathrm{e}}
\end{aligned}
$$

The $\mathrm{U}^{233}$ isotope produced in step (3), when bombarded with neutrons, undergoes fission into fragments of lighter nuclei, releasing two neutrons.

$$
{ }_{92} \mathrm{U}^{233}+{ }_{0} \mathrm{n}^{1} \rightarrow \text { fission fragments }+2{ }_{0} \mathrm{n}^{1}
$$

Of the two neutrons produced from step (4) one can be used to produce another $\mathrm{U}^{233}$ and the second one to cause fission and sustain a chain reaction, only if all the neutrons generated are utilized, which is never realized. This explains why $\mathrm{Th}^{232}$ alone cannot be used to make a bomb or a reactor. The situation is different if a substantial amount of $\mathrm{U}^{233}$ is neutron bombarded. As each neutron now reproduces two neutrons a chain reaction can be achieved. Initially in a normal uranium reactor, thorium can be irradiated to yield $\mathrm{U}^{233}$ which undergoes fission. Designs are possible that subsequently, the reactor runs only on thorium (Uhlir, 2007; Anantharaman, et al.,2008). Indira Gandhi Center for Atomic Research (IGCAR) at Kalpakkam, Tamil Nadu, India has already developed fast breeder reactors (Bagla, 2005), which will eventually use thorium as the feeding fuel. The only operating reactor in the world KAMINI (Kalpakkam mini reactor) that utilizes thorium derived $\mathrm{U}^{233}$ is also located at IGCAR. In KAMINI, the fuel material is an alloy of $\mathrm{U}^{233}$ and aluminum (Anantharaman et al.,2008). The liquid fluoride thorium reactor (LFTR), experimentally tested at the Oak Ridge National Laboratory, USA is also a thorium breeder reactor, which uses a molten salt mixture as the coolant (Uhlir, 2007). The advantage of the LFTR is that the fuel in the form of $\mathrm{UF}_{4}$ and $\mathrm{ThF}_{4}$ could also be dissolved in the coolant. China announced its plans for development of LFTR reactors in January 2011 (Wikio News, 2011). The liquid fluoride systems can be scaled down to megawatt capacities and in fact it was the reactor concept considered for powering an aircraft (Hargraves \& Moir, 2010). Japan is planning 10MW LFTRs to provide electricity for charging electric vehicles (Wikio News, 2011).

There is also an important difference between $U^{233}$ and $\mathrm{U}^{235}$. In the case of $\mathrm{U}^{233}$, the fission induced by a neutron yields two daughter neutrons, whereas in the case of $\mathrm{U}^{235}$, the yield of daughter neutrons could be two or three. However, the probability of neutron induced fission is higher in $U^{233}$ than in $U^{235}$. Thus, in principle, $U^{233}$ can also be used to make a bomb, but the practical difficulty is that $\mathrm{U}^{233}$ derived from thorium is contaminated with deleterious isotopes. 
Thorium nuclear reactor designs receiving much attention currently are accelerator driven systems (Nefenecker et al., 2003). Here, neutrons generated via bombardment of protons from an accelerator on a suitable target are directed to transmute $\mathrm{Th}^{232}$ to $\mathrm{U}^{233}$. An immense advantage of this concept over conventional reactors is the possibility of switching off the reactor by turning off the accelerator. Fission-fusion hybrids have also been considered for utilization of thorium. The idea is using neutrons from a fusion system for converting $\mathrm{Th}^{232}$ to $\mathrm{U}^{233}$. Although the current plasma fusion devices in their present form cannot generate practical power, the neutron flux may be sufficient to drive a fission reaction in a thorium reactor.

The incidents at the Fukushima reactors in Japan after the quake on $11^{\text {th }}$ March 2011 have resurfaced concerns regarding the safety of nuclear power. Understanding conditions that led to the Fukushima reactor accident will make clear that this is no cause for abandoning nuclear power. Every reactor has a built - in safety mechanism to stop the chain reaction to prevent meltdown if the cooling system fails. The signal of a tremor had activated the safety device, but even if the chain reaction stops, the radioactive decay products that had accumulated will continue to generate some heat (referred to as decay heat), sufficient for a partial meltdown if the alternative cooling system also fails. A most unlikely coincidence of events has been the cause of the Fukushima accident. New generations of reactors will certainly incorporate additional precautionary measures. Meltdown of proof reactor designs are fairly well studied and in this context, thorium based systems possess more advantageous features (Uhlir, 2007; Penny, 2010). However, it is important to note that no reactor, including the accelerator driven systems, are intrinsically free of meltdown risk, unless adequate precautionary measures are incorporated. It appears that relatively small thorium based systems with a natural convection safeguard to dissipate decay heat after an emergency shut-down are the safest reactors.

\section{Conclusion}

Sri Lanka is richly endowed with thorium minerals that are scientifically and economically important and also unique. Sri Lankan thorianite, thorite and monazites contain a relatively higher percentage of thorium compared to similar deposits elsewhere. Generally, these ores have a higher Th: $\mathrm{U}$ ratio, partly understood as due to metamictization and hydrologic weathering, two effects to which thorium ores offer resistance.

After the discovery of radioactivity, when Marie Curie found pitchblende to be more radioactive than pure uranium, researchers in Europe made intense efforts to search pitchblende and other radioactive minerals all over the world. Few inquisitive British planters in Sri Lanka, being aware of these developments, seemed to have prospected their neighbourhoods and sent samples to prominent scientists in Britain. Subsequently, Mineralogical Survey of Ceylon identified deposits of thorianite, thorite and monazite. In the early days of radioactivity, thorianite from Ceylon was only second to pitchblende in experimentation, leading to major discoveries by the key figures who worked in this field. Leading scientific journals in physics and chemistry during the first three decades of the twentieth century carry numerous articles making conspicuous references to Ceylon thorium minerals. During the World War I, Ceylon thorium minerals received the attention of the British Government as a source of helium for airships. Similarly at the time of the World War II, Ceylon monazite was considered as a strategic material for nuclear weaponry. However, thorium minerals have never been processed in large scale to extract thorium for the purpose of nuclear energy and current commercial use of monazite is mainly for recovery of rare earths. The ease of achieving a chain reaction with uranium, weapon development and identification of substantial uranium reserves are the reasons for neglecting exploitation of thorium for nuclear energy. Escalating global energy demand, depletion of fossil fuels and absolute necessity of curtailing green-house gas emissions require alternative sources of energy. In this context thorium seems to be the saviour of humanity from energy starvation and pollution. Thorium is abundant and admits more environmentally friendly and safer reactor designs. Commissioning of thorium based reactors could take one to two decades from initiation of feasibility studies and also depend on developments of this sector in the international arena (Jayewardene, 2010; Ranaweera, 2010). Development and even the sustenance of present comforts of living in the future require consumption of larger quantities of energy, making nuclear option unavoidable (Ranawake, 2011). Most important is the availability of a pool of human resource-physicists, chemists, geologists, engineers and technicians who could plan and manage such programmes. The country needs to motivate and attract the younger generation to studies leading to above careers through indigenous research. For this purpose it is imperatively essential that research in the universities is strengthened and the teaching upgraded. Now it is more than one hundred years after discovery of radioactivity and the centennial anniversary of the award of Nobel Prize in Chemistry is celebrated in this year (2011). The International Year of Chemistry is an appropriate moment to initiate indigenous research geared to exploit the thorium resource of the country. 


\section{References}

1. Abraham I. (1998). Making of the Indian Atom Bomb, pp. 10-130. Zet Books Limited, New York, USA.

2. Anantharaman A., Shivakumar V. \& Saha D. (2008). Utilization of thorium in reactors. Journal of Nuclear Materials 383(2):114-121.

3. Anderson B.W., Claringbull G.F., Davis R.J. \& Hill D.K.(1961). Ekanite, a new metamict mineral from Ceylon. Nature 192(4780): 997-997.

4. Anderson B.W. (1974). The pleasure of discovery. Journal of Gemology 14(12): 34-37.

5. Arnett D. (1996). Supernovae and Nuclear Synthesis, pp. 124-152. Princeton University Press, New York, USA.

6. Badash F. (1979). The suicidal success of radiochemistry. The British Journal for History of Science 12(42):245-246.

7. Bagla P. (2005). Rethinking nuclear power: India's homegrown thorium reactor. Science 309(5738): 1174-1175

8. Barghusen J. \& Smutz M.(1958). Processing monazite sands. Industrial Engineering Chemistry 50(12):1754-1755.

9. Becquerel A.H. (1903). On radioactivity, a new property of matter. Nobel Lecture, December 12. Nobel Foundation, Stockholm, Sweden.

10. Boltwood B.B. (1907). Ultimate disintegration products of radioactive elements. American Journal of Science 134(4):6-88.

11. Bostock J. \& Riley H.T.(1898). Natural History of Pliny (translation), pp. 28-120. George Bell and Sons, London, UK.

12. Chalmers M. (2010). Enter the thorium tiger. Physics World October 2010: 40-46.

13. Clery D. (2005). Nuclear industry dares to dream of a new dawn. Science 309(5738):1172-1175.

14. Coomaraswamy A.K. (1903). Mineralogical Survey of Ceylon. Administrative Report No. L1-L12. Dept. of Mineralogical Survey, Ceylon.

15. Coomaraswamy A.K. (1904a). Report on Thorianite and Thorite, pp.1-4. Government Printing Office, Colombo.

16. Coomaraswamy A.K. (1904b). Uraninite. Spolia Zeylanica 6(2) :57-57.

17. Cowan G.A. (1976). A natural fission reactor. Scientific American 235(1):36-47.

18. Crooks T. (1908). Economic Geology. Imperial Mineral Resources Bureau, London, UK.

19. Crooks W. (1908). On Scandium. Chemical News Dcember 4:274-275.

20. Crouse D. \& Brown K. (1959). The Amex process for extracting thorium ores with alkyl amines. Industrial Engineering Chemistry 51(8):1461-1469.

21. Curie M. (1911). Radium concepts in chemistry, Nobel Lecture, December 11, Nobel Foundation, Stockholm, Sweden.

22. Current Industrial News (1917). Industrial Monazite Sand. In: Industrial and Engineering Chemistry, pp.1063-1065. Current Industrial News, American Chemical Society, New York, USA.
23. Dalrymple G.B. (1992). The Age of Earth, pp. 305-357. Stanford Press, Stanford, USA.

24. Davis D.W. \& Krough T.E. (2003). Historical development of zircon geochronology. Reviews of Mineralogy and Geochemistry 53(2): 145-181.

25. Davy J. (1821). An Account of the Interior of Ceylon and its Inhabitants with Travels in that Island, pp. 16-33. Longman, London, UK.

26. Delft van D. (2008). Little cup of helium, big science. Physics Today 61(3): 36-42.

27. De Costa S. \& Nandadeva S.A. (2001). The mechanism of deposition of heavy minerals on beach by wave action- Sri Lankan case. Available at http//:www.sahr.orgle-library. bejing. Accessed 15 February 2011.

28. De Silva N. (2008). Ekanite- Discovery of a new rare gemstone by Mr. F.D.L.Ekanayake. Available at http//:www. jewelry-blog.internetstones.com. Accessed 15 February 2011.

29. Dewar J. (1927). Collected Papers, Cambridge University Press, Cambridge, UK.

30. Dharmawardene K.G., Rajapaksa P.R.D. \& Jayaratne C. (1986). Radioactive technique for measurement of wave activity on sea shore. Proceedings of Technical Sessions of the Institute of Physics, Sri Lanka, 29 March, Institute of Physics, Vidya Mandiraya, 120/10, Wijerama Mawatha, Colombo 7. pp.c3.

31. Dunstan W. R. (1904). The occurrence of thorium in Ceylon. Nature 69(March 31): 510-511.

32. Dunstan W. R. \& Blake A.R.S.M. (1905). Thorianite, a new mineral from Ceylon. Proceedings of the Royal Society of London 76(88):510-533.

33. Dunstan W. R. (1905). Report of the results of the mineral survey of Ceylon, 1903-1904, pp. 3-34. Great Britain, Colonial Office, Ceylon.

34. Dunstan W.R. \& Jones M. (1906). A variety of Thorianite from Galle, Ceylon. Proceedings of the Royal Society of London 77(91): 546-549.

35. Emsley J. (2001). Nature's Building Blocks: An A-Z Guide to the Elements, pp. 230-285. Oxford University Press, Oxford, UK.

36. Ewing R.C., Meldrum A., Wang L., Weker W.J. \& Corrales L.R. (2003). Reviews in Mineralogy and Geochemistry 53(1): 387-425.

37. Fletcher L. (1893). On baddeleyite, new mineral from Rakwana, Ceylon. Mineralogical Magazine 54(6): 160166.

38. Genet M. (1995). The discovery of uranic rays: a short step for Henri Becquerel but giant step for science. Radiochemica Acta 70/71(1): 3-12.

39. Great Britain Board of Trade (1906). The Board of Trade Journal, p.33. Great Britain Board of Trade, London, UK.

40. Gubelin E.J.(1962). Ekanite. The Gemmologist 31(1962): 142-152.

41. Gleditsch E. (1908). Radium and uranium content in Minerals. Competes Rendus 148(39): 1451-1453.

42. Gotteried D.(1953). The age and relationships of radioactivity and lead contained physical properties of zircon crystals from Ceylon. American Geophysical Union 
Transactions 34(2):342-349.

43. Gotteried D., Senftle F.E. \& Waring C.L. (1956). Age determination of zircon crystals from Ceylon. American Mineralogist 41(8):157-161.

44. Guha R.(2007). India after Gandhi: The History of the World's Largest Democracy, pp. 115-209. Harper Collins, New York, USA.

45. Hahn O. (1905). A new radioactive element that evolves thorium emanation. Nature 71(11): 574-574.

46. Hahn O. (1907). Origin of radium. Nature 77(14):30-31.

47. Hargraves R. \& Moir N. (2010). Liquid thorium reactors. American Scientist 98(July-August):304-313.

48. Hazen R.M., Ewing R.C. \& Sverjensky D.A. (2004). Evolution of Uranium and Thorium Minerals. American Mineralogist 94(2): 1293-1311.

49. His Majesty's Stationery Office (1920). Mineral industry of the British Empire and Foreign Countries, War Period (1813-1919). His Majesty's Stationery Office, London, UK.

50. Hoffmann K .(1993). Otto Hahn, Achievement and Responsibility, pp. 33-1997. Springer, Berlin, Germany.

51. Holmes A.(1 927). The Age of Earth, Harper and Brothers, New York, USA.

52. Imperial Institute, London (1916). Recent work on monazite and other thorium minerals in Ceylon. Bulletin of the Imperial Institute, London 14(3): 321-369.

53. Jayewardene D. (2010) The potential of nuclear power in Sri Lanka. The Island, 24 February.

54. Jobbins E.A., Tresham A.E. \& Young B.R. (1977). Gem monazite from Sri Lanka. Journal of Gemmology 15(9): 295-299.

55. Kanazawa Y. \& Kamitani M. (2005). Rare earth minerals and resources of the world. Journal of Alloys and Compounds 408(2):1339-1343.

56. Kauffman G.B. (1982).The atomic weight of lead of radioactive origin: a confirmation of the concept of isotopy and group displacement law. Journal of Chemical Education 59(8):119-125.

57. Kremers H.E. (1985).Technology of rare earths. Journal of Chemical Education 62(7):1461-1364

58. Kulp J.L., Volchok H.L. \& Holland H.P.(1952). Age from metamict minerals. The American Mineralogist 37(3):709719.

59. Kunz G.F.(1915). The Magic of Jewels and Charms, pp. 56-189. J.B. Lippincot Co., Philadelphia, USA.

60. Lang S.B.(2005). Pyroelectricity: from ancient curiosity to modern imaging tool. Physics Today 58(8):31-36.

61. Levy S.L.(1915). Rare Earths, pp. 10-123. Edwards Arnolds, London, UK.

62. Lykkens A., Kragh H. \& Kwittngen N. (2004). Ellen Gleditsch- pioneer woman in radiochemistry. Physics in Perspective 6(2):136-155.

63. Mahawatta P. \& Hewamanna R.(1991). Absolute alpha activity measurements of some plants growing in monazite bearing soils in Sri Lanka, International Journal of Radiation Application and Instrumentation, Part D-Nuclear Tracks and Radiation Measurement 19(9): 775-780.

64. Murakami T., Chakolumakos B.C., Ewing R.C., Lumpkin
G.R. \& Weber W.J. (1991). Alpha-decay event damage in zircon. American Mineralogist 76(7): 1510-1532.

65. Nasdala L., Reiners P.W., Garner J.L., Kennedy A.K., Strern R.A., Balan E. \& Wirth R. (2004). American Mieralogist 89(8):219-321.

66. Nefenecker H., Meplan O. \& David S. (2003). Accelerator Driven Subcritical Reactors, pp.190-207. IOP Publishing, London, UK.

67. Ni et al. (1995). Crystal chemistry of monazite and xenotime structures. American Mineralogist 80(3):21-26.

68. Nininger R.D. (1954). Minerals for Atomic Energy, pp. 3-198. Van Nostrand, New York, USA.

69. Nier A.O. (1939). The isotopic constitution of radiogenic lead and measurement of geological time. Physical Reviews 55(2): 153-163.

70. Ogawa M. (1909). On new element in thorianite. Journal of the Tokyo Chemical Society 30(1):1277-1299.

71. Overstreet W.C. (1967). The geologic occurrence of monazite, Professional Paper 530, US Geologial Survey, Reston, Virginia, USA.

72. Pascoe E.H. (1924).Monazite sands and other sources of thoria. Nature 113(2843):607-607.

73. Penny S.L. (2010). A study of the advantages of thorium based reactors for nuclear power, Ph.D. dissertation, Department of Physics, University of Surrey, UK.

74. Ramsay W. \& Soody F. (1903). Experiments in radioactivity and production of helium from radium. Proceedings of the Royal Society of London 68(477): 204-207.

75. Ramsay W. (1904). A new mineral from Ceylon. Nature 69(April 7): 533-533.

76. Ranawake P.C. (2011). Future world energy requirement. Daily News, 22 March.

77. Ranaweera A. (2010). Thorium as an energy sourceopportunities for Sri Lanka. The Island, 10 November.

78. Richards T.W. (1914). Atomic weight of lead of radioactive origin. Journal of the American Chemical Society 36(7): 1329-1344.

79. Rutherford E. (1906). Radioactive Transformations, pp. 179-195. C.Scribner's Sons, London, UK.

80. Rutherford E. (1930). Some cosmical aspects of radioactivity. Journal of the Royal Astronomical Society of Canada 1(1): 145-165.

81. Science Service (1930). British sea sand as source of helium for airships. Journal of Chemical Education 24(7): 2149-2151.

82. Slingerland R. \& Smith N.D. (1986). Occurrence and formation of water laid placers. Annual Review of Earth and Planetary Science 14(1986): 113-147.

83. Soddy F. (1904). Origin of the conception of isotopes. Nature 112(June 16): 208-213.

84. Soddy F. \& Hyman H. (1914). The atomic weight of lead from Ceylon thorite. Journal of the Chemical Society, Transactions 105(2): 1402-1408.

85. Soddy F. (1915). Density of lead from Ceylon thorite. Nature 94(February 4):615-615.

86. Soddy F. (1917). Atomic weight of thorium lead. Nature 98(February 4): 469-469. 
87. Soddy F. (1919). End-product of thorium. Nature 102(February 6): 444-445.

88. Soddy F. (1922). The origin of the conception of isotopes, Nobel Lecture, December 12, Nobel Foundation, Stockholm, Sweden.

89. Sorkhabi R.(2008). Ananda K. Coomaraswamy: geology to philosophia. Current Science 94(3):394-401.

90. Strutt R.J. (1909). Direct estimate of the minimum age of thorianite. Nature 80(May 13):308-308

91. Stuart A.A.(1929). Liquid helium boils on ice and freezes tin. Popular Science February: 28-29.

92. Tabutea A., Pages M., Livet J. \& Musikas J.(1988). Monazite like phases containing transuranium elements (neptunium, plutonium). Journal of Material Science Letters 7(6):1315-1317.

93. Tennent J.M.(1860). Ceylon: an Account of the Island, Physical, Historical and Topographical with Notices of its Natural History and Productions, volume I, 5th edition, pp. 3-89. Longman, London, UK.

94. Thomas J.M.(2008). Lord Rutherford (1871-1937): winner of the Nobel Prize for Chemistry 1908. Angewandte Chemie 41(1):9392-9401.

95. Thompson J.J. (1905). On emission of negative corpuscles by alkali metals. Philosophical Magazine Series 6 10(8):584-590.

96. Titaeva N.A. (2000). Nuclear Geochemistry, pp.45-93. CRC Press, Boca Raton, Florida, USA.

97. Uhlir J.(2007). Chemistry and technology of molten salt reactors-history and perspectives. Journal of Nuclear Materials 360(1): 6-11.

98. Unak T.(2000). What is the potential of the use of thorium for energy production? Progress in Nuclear Energy 37(14):137-144.

99. Wadia D.N. \& Fernando L.J.D. (1946). Ilmenite, monazite, zircon and gems and semi-precious stones. Geological Magazine 83(2): 200-232.

100. Wickramaratne W.S. (1986). Preliminary studies of the offshore occurrences of monazite-bearing heavy placers, southwestern Sri Lanka. Marine Geology 72(6):1- 4.

101. Wijayananda N.P. \& Nootan G.A. (2000). Oceans 2000MTS/IEEE Conference and Exhibition, pp. 16111619. IEEE Service Center, New Jersey, USA.

102. Wikio News (2011). China's thorium reactor and Japan's targets $10 \mathrm{MW}$ thorium mini-Fuji for 2016, Wikio News 02-16-2011. http://www.nextfuture.com/. Accessed 15 February 2010.

103. Williams M.L., Jercinovicz M.J. \& Hetherinton C. (2007). Microprobe monazite geochronology: integrating composition and chronology. Annual Review of Earth and Planetary Science 35(8): 137-175.

104. Yoshihara H.K. (2008). Nipponium as a new element $(Z=75)$ separated by the Japanese chemist, Masataka Ogawa: a scientific and science historical re-evaluation. Proceedings of the Japan Academy Series B 84(3):232245. 